\title{
Studi Literatur: Pengaruh Problem Based Learning Terhadap Kemampuan Matematis Siswa
}

\author{
Amarta Prayuti, ${ }^{1, a)}$, Tian Abdul Aziz ${ }^{2, b)}$, Makmuri ${ }^{3, c)}$ \\ ${ }^{123}$ Universitas Negeri Jakarta, Rawamangun, Jakarta Timur

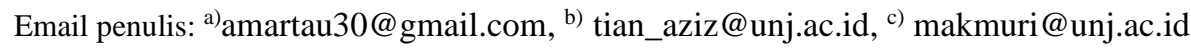

\begin{abstract}
Education in Indonesia is still far from perfect education. The PISA and TIMSS results state that the mathematical abilities of students in Indonesia are still low. In fact, students' mathematical abilities are important for their application in solving real-world problems. One of the solutions is to select the appropriate learning model for the students' abilities. The purpose of this study is to see which mathematical abilities will develop with the Problem Based Learning model. The research method used is a literature study with a qualitative approach to content analysis techniques. 10 articles were selected from accredited articles Sinta 1 to Sinta 5 and selected titles related to the Problem Based Learning model and students' mathematical abilities. The results showed that the Problem Based Learning model can improve students' critical thinking skills, creative thinking skills and problem-solving skills, as well as the relationship between the three. Furthermore, this article also discusses specific strategies combined with the Problem Based Learning model to make learning more meaningful. Educators can use the Problem Based Learning model as a reference for teaching and the researcher can further investigate other mathematical abilities that have an effect when applying the Problem Based Learning model.
\end{abstract}

Keywords: Problem Based Learning, Student's Mathematical Abilities

\begin{abstract}
Abstrak
Pendidikan di Indonesia masih jauh dari kata sempurna. Hasil PISA dan TIMSS menyatakan bahwa kemampuan matematis siswa di Indonesia masih tergolong rendah. Padahal, kemampuan matematis siswa penting untuk penerapannya dalam menyelesaikan masalah di dunia nyata. Salah satu solusinya adalah dengan pemilihan model pembelajaran yang tepat dengan kemampuan siswa. Tujuan dari penelitian ini adalah melihat kemampuan matematis apa saja yang akan berkembang dengan model pembelajaran Problem Based Learning. Metode Penelitian yang digunakan adalah Studi Literatur dengan pendekatan kualitatif teknik Content Analysis. Dipilih 10 artikel dari artikel terakreditasi sinta 1 sampai sinta 5 dan dipilih judul-judul yang berkaitan dengan model pembelajaran Problem Based Learning dan kemampuan matematis siswa. Hasil penelitian menunjukkan bahwa model Problem Based Learning dapat meningkatkan kemampuan matematis siswa diantaranya kemampuan berpikir kritis, kemampuan berpikir kreatif dan kemampuan pemecahan masalah, serta keterkaitan diantara ketiganya. Lebih jauh lagi artikel ini juga membahas strategi-strategi khusus yang dipadukan dengan model Problem Based Learning agar pembelajaran semakin bermakna. Pendidik dapat menggunakan model Problem Based Learning sebagai referensi pengajaran di sekolah serta Peneliti dapat meneliti lebih lanjut kemampuan matematis siswa lainnya yang berpengaruh jika menerapkan model Problem Based Learning.
\end{abstract}

Kata kunci: Problem Based Learning, Kemampuan Matematis Siswa

Copyright (c) 2021 Prayuti, Aziz, Makmuri

$\triangle$ Corresponding author:

Email Address: amartau30@gmail.com

Received 27 Januari 2021, Accepted 9 Agustus 2021, Published 20 Agustus 2021

https://doi.org/10.21009/jrpmj.v3i2.22266

\section{PENDAHULUAN}

Pendidikan di Indonesia dituntut untuk memiliki kompetensi-kompetensi diri yang dapat bermanfaat bagi peserta didik dalam menjalani kehidupannya sehari-hari. Kompetensi-kompetensi diri 
tersebut diantaranya memiliki kekuatan spiritual keagamaan, pengendalian diri, kepribadian, kecerdasan, akhlak mulia, serta keterampilan lain yang ada dalam kehidupan berbangsa dan bernegara (UU RI No. 20 Tahun 2003, 2003). Menurut data Foundation for Young Australians, Kompetensi diri yang dibutuhkan saat ini adalah kemampuan-kemampuan yang dibutuhkan di dunia kerja (Enterprise skills). Kompetensi ini juga memungkinkan siswa untuk dapat berkontribusi di dunia yang kompleks dan menjawab tantangan-tantangan yang akan mereka hadapi. Kompetensi tersebut diantaranya kemampuan pemecahan masalah (problem solving), kemampuan komunikasi (communications), kemampuan literasi keuangan (financial literacy), kemampuan berpikir kritis (critical thinking), kemampuan berpikir kreatif (creativity), kemampuan bekerja dalam kelompok (teamwork), kemampuan literasi digital (digital literacy) dan kemampuan presentasi (presentation skills) (Foundation for Young Australians, 2016). Sesuai dengan kompetensi yang dirancang dalam kurikulum 2013 diantaranya adalah kompetensi 4C yang juga selaras dengan $21^{\text {st }}$ Century Partnership Learning Framework yaitu Critical thinking/problem-solving, Creativity, Communication, dan Collaboration (Partnership for 21st Century learning, 2009).

Namun, berdasarkan data PISA sejak tahun 2003 - 2018 dan TIMSS sejak tahun 1999 - 2015, siswa di Indonesia masih kesulitan dengan soal bertaraf tinggi yang dapat dipecahkan dengan kemampuan berpikir tingkat tinggi, diantaranya kemampuan pemecahan masalah dan kemampuan berpikir kritis. Kemampuan dan pemahaman konsep siswa juga masih tergolong sangat lemah (Gunur et al., 2019; Sunardi, 2016). PISA tahun 2018, Indonesia menduduki peringkat ke-74 dari 79 negara atau sama dengan peringkat keenam dari bawah. Dalam kategori Matematika, Indonesia mendapat skor 379 sedangkan rata-rata skor OECD (Organisation for Economic Co-Operation and Development) adalah 489. Perbandingan ini jauh dibawah rata-rata dan mengalami penurunan skor disetiap bidang (Sains, Matematika, dan Membaca) hingga kurang lebih 10 skor. Indonesia masih kalah saing dengan negara-negara lain seperti Panama, Georgia, Kazakhstan, Thailand, Malaysia. dan negara-negara lainnya (Schleicher, 2019). Peringkat 46 dari 51 negara didapatkan Indonesia dalam TIMSS (2015) atau sama dengan peringkat 5 dari bawah. Ditambah dengan minat siswa yang kurang untuk mempelajari matematika karena dianggap beban karena harus mengingat dan menghafal banyak hal abstrak dan tidak aplikatif, serta tidak merasa penting bagi kehidupannya (Yusri, 2018).

Pemilihan model menjadi salah satu faktor yang berpengaruh dalam proses belajar dan pembelajaran (Nurlaeli et al., 2018). Menurut Joyce, Model Pembelajaran adalah sebuah perencanaan yang digunakan sebagai pedoman dalam merancang suatu pembelajaran (Joyce et al., 1992). Model pembelajaran seharusnya relevan dan mendukung untuk mencapai tujuan pembelajaran (Yusri, 2018). Teacher centered masih menjadi praktik yang dominan dalam proses pembelajaran di kelas. Padahal, menurut Faridah, Teacher Centered adalah permasalahan dalam pendidikan di Indonesia dan cara optimalisasi peran guru pada kurikulum 2013 adalah salah satunya guru sebagai sumber belajar, fasilitator, pengelola, demonstrator, pembimbing, motivator, dan evaluator (Alawiyah, 2013). 
Untuk meningkatkan keaktifan siswa dalam belajar, dibutuhkan model pembelajaran yang berpusat pada siswa. Salah satu model pembelajaran tersebut adalah Problem Based Learning (Fathurrohman, 2001; Prasetya, 2013). Model pembelajaran yang akan difokuskan dalam penelitian ini adalah irisan dari penemuan-penemuan model pembelajaran yang berfokus pada siswa yaitu Problem Based Learning. Model Pembelajaran Problem Based Learning adalah Model pembelajaran yang berfokus pada pemecahan masalah yang berkaitan dengan kehidupan sehari-hari. Model pembelajaran Problem Based Learning memiliki beberapa karakteristik. Pada awal penerapan model Problem Based Learning, guru menanyakan atau menampilkan permasalahan yang bersifat nyata ada di kehidupan sehari-hari. Kemudian guru menggiring siswa untuk mengkoneksikan masalah yang ditampilkan dengan bidang ilmu yang saat itu sedang dipelajari. Pada tahapan ini, guru juga bisa mengarahkan siswa untuk berdiskusi dengan teman-temannya dan mengembangkan kemampuan berkomunikasinya. Setelah itu, masuk ke proses pemecahan masalah. Setelah itu analisis permasalahan lalu menemukan solusinya. Guru membantu siswa untuk mengevaluasi dan mereview kembali mulai dari masalah itu dinyatakan hingga diselesaikan. Karakteristik lainnya adalah Model Problem Based Learning ini adalah pembelajaran berpusat pada siswa (Cahyaningsih \& Ghufron, 2016).

Sintak Problem Based Learning menurut Barret (Barrett, 2016) dimulai dengan guru memberikan masalah kepada siswa dilanjutkan dengan membuat kelompok kecil sehingga siswa dapat berdiskusi dan mengumpulkan informasi. Siswa belajar secara mandiri dengan menggali pengetahuan dari sumber-sumber yang mereka punya seperti buku, internet, orang lain, dan sumber lainnya kemudian membagi informasi tersebut kepada teman-temannya dengan cara tutor sebaya untuk menyelesaikan masalah. Siswa mempresentasikan solusi atas masalah tersebut. Pada tahapan terakhir, siswa mereview kembali apa yang sudah mereka kerjakan dan pelajari, serta guru menuntun siswa untuk merefleksikan evaluasi apa yang masih ada agar selanjutnya bisa diperbaiki.

Sintak Problem Based Learning menurut Yongwu Miao (Miao et al., 2020) dimulai dengan tahap mengidentifikasi masalah, yaitu guru memperkenalkan masalah secara garis besar dan membiarkan siswa belajar memecah masalah menjadi beberapa bagian. Pada tahap ini siswa akan menggali kemampuan pemecahan masalahnya. Guru dapat membantu dengan cara memberi petunjuk atau pertanyaan-pertanyaan kritis yang membantu siswa berpikir ketika memecah permasalahan tersebut. Tahap berikutnya adalah mengidentifikasi masalah pembelajaran, dimana siswa menghubungkan antara pengetahuan yang telah mereka peroleh dengan masalah yang sudah dipecah sebelumnya. Siswa akan mendapatkan gambaran besar permasalahan beserta partisi-partisi lain yang masih kurang dan dibutuhkan untuk melengkapi solusi dari permasalahan yang disajikan. Siswa menetapkan tujuan, membuat rencana, memahami ilmunya dan mengaplikasikan ilmu yang telah ia miliki. Proses awal sampai tahap ini bisa berulang sesuai kebutuhan Pada tahapan terakhir yaitu guru bersama siswa menilai dan mengevaluasi pembelajaran, serta memberi kesimpulan dan motivasi kepada siswa. 
Model Problem Based Learning mempunyai kelebihan dan kekurangan (Wulandari \& Surjono, 2013; Yulianti \& Gunawan, 2019). Kelebihan dalam model Problem Based Learning adalah Model Problem Based Learning dapat meningkatkan aktivitas pembelajaran siswa, Proses-proses dalam sintak Problem Based Learning membantu siswa untuk memahami masalah-masalah yang ada, diantaranya proses pemecahan masalah yang menjadi inti dari model ini. Kemudian membantu siswa dalam mengembangkan pengetahuannya dan bertanggung jawab atas jawabannya. Siswa dapat memahami cara belajar bukan sekedar hanya menghapal. Masalah-masalah yang menjadi contoh bisa diimplementasikan kedalam kehidupan siswa. Namun, disamping kelebihan model ini, juga terdapat kekurangan diantaranya apabila siswa tidak memahami masalah yang dihadapkan diawal model Problem Based Learning atau siswa tidak terlalu mempunyai minat dalam belajar matematika maka siswa akan mudah menyerah. Disamping itu, Model ini juga membutuhkan proses yang cukup panjang dalam persiapannya.

Berdasarkan penjelasan yang sudah dipaparkan sebelumnya, maka dibutuhkan fokus yang membahas tentang kemampuan matematis siswa yang berkembang dengan menggunakan model pembelajaran Problem Based Learning. Dengan kata lain, rumusan masalah pada artikel ini adalah "Kemampuan matematis siswa apa saja yang dapat ditingkatkan dengan Problem Based Learning?". Tujuan dari pembuatan artikel ini adalah untuk mengetahui Kemampuan Matematis apa saja yang berkembang jika dalam pembelajaran menerapkan model Problem Based Learning. Penelitian ini penting untuk dibahas karena dibutuhkan dalam kehidupan nyata manusia dan untuk mempermudah para pendidik dalam proses belajar mengajar di sekolah agar apa yang menjadi tujuan dalam pembelajaran dapat tercapai.

\section{METODE}

Penelitian ini berisi analisis tentang masalah siswa pada mata pelajaran matematika, solusinya pada sintak model pembelajaran Problem Based Learning, dan kaitannya dengan kemampuan matematis siswa. Penelitian ini menggunakan metode studi literatur dengan pendekatan kualitatif. Objek kajian pada artikel ini adalah artikel-artikel terakreditasi Sinta 1 - Sinta 5 dan dipilih artikelartikel yang cocok dengan judul penelitian. Pada subbab pembahasan akan dibahas beberapa kemampuan matematis siswa diantaranya kemampuan berpikir kritis ( 3 artikel), kemampuan berpikir kreatif (4 artikel) dan kemampuan pemecahan masalah (4 artikel). Teknik analisis yang digunakan adalah teknik Content Analysis. Data yang digunakan untuk dianalisis adalah data-data pada artikel yang dianalisis.

\section{HASIL DAN PEMBAHASAN}

Menurut NCTM, Daya Matematis meliputi kemampuan mengeksplorasi, menduga dan menalar secara logis untuk memecahkan masalah, kemampuan berkomunikasi dengan logika matematika, dan 
untuk mengaitkan ide-ide yang ada di matematika dengan aktivitas intelektual lainnya (kemampuan koneksi)(NCTM, 2000). Menurut Pinellas County School, Daya matematis dikategorikan menjadi tiga bagian. yaitu:

1. Standar Konten (Content Standards) adalah kompetensi dasar bagi suatu kurikulum yaitu Pengertian dan Konsep Angka, Pengukuran, Geometri dan Pengetahuan Spasial, Aljabar, Analisis Data dan Probabilitas.

2. Kemampuan Matematis (Mathematical Abilities) adalah kemampuan untuk dapat memanipulasi matematika diantaranya pemahaman konsep dan pengetahuan prosedural.

3. Standar Proses (Process Standards) adalah standar tujuan yang akan dicapai dalam proses pembelajaran..

Dalam artikel ini akan dikaji lebih lanjut mengenai kemampuan berpikir kritis, kemampuan berpikir kreatif dan kemampuan pemecahan masalah.

\section{Kemampuan Berpikir Kritis}

Berpikir kritis menurut Facione, terdapat empat bagian yang diperinci diantaranya mengidentifikasi elemen kritis berupa menganalisis lingkungan strategis, mengidentifikasi elemenelemen dan hubungan diantaranya, menginterpretasikan peristiwa dan elemen lain dalam lingkungan tersebut untuk melihat SWOT. Kemudian melihat konsekuensi yang logis dan memprediksi kemungkinan resiko dan ketidakpastian dengan menginferensi kemungkinan-kemungkinan yang ada. Tahapan terakhir yaitu membuat keputusan dengan mengevaluasi SWOT dan menjelaskan secara rasional (Facione, 2015). Menurut Pascarella dan Terenzini, kriteria berpikir kritis antara lain adalah mengidentifikasi masalah, mengenali keterkaitan yang penting, menyimpulkan data, menyimpulkan informasi, mengintepretasi kemungkinan hasil berdasarkan informasi yang didapat, mengevaluasi fakta-fakta atau sumber, mengoreksi, dan menyelesaikan masalah (Pascarella \& Terenzini, 2005). Menurut Fisher, terdapat lima aspek berpikir kritis yaitu, mengidentifikasi masalah, menemukan solusi, memberikan alasan, memeriksa kembali, dan memberi kesimpulan (Fisher, 2009). Secara garis besar, kriteria kemampuan berpikir kritis yang telah diteliti oleh para ahli tidak jauh berbeda. Dimulai dengan menelaah masalah, menganalisis masalah, menyimpulkan data dan informasi yang ada dalam masalah tersebut, memecah masalah dengan solusi atau menemukan solusi, mengevaluasi hasil pemecahan masalah, dan menyelesaikan masalah dengan penjelasan.

Kemampuan berpikir kritis siswa akan meningkat jika kita dapat pintar memilih model-model pembelajaran dan strategi yang sesuai dengan kapabilitas siswa (Kusumaningtias et al., 2013). Beberapa artikel menunjukkan bahwa model Problem Based Learning dapat menjadi solusi untuk meningkatkan kemampuan berpikir kritis siswa (Gunur et al., 2019). Kemampuan berpikir kritis dapat berkembang jika sengaja dilatih dan dikembangkan tentunya dengan waktu yang cukup. upaya pengembangan dapat dilakukan melalui aktivitas pembelajaran. selanjutnya kemampuan berpikir kritis akan berkembang serta memicu perkembangan kemampuan lain seperti kemampuan metakognitif siswa. 
Penelitian Problem Based Learning untuk meningkatkan Kemampuan Berpikir Kritis siswa berbantu masalah open-ended memberikan pengaruh positif (Gunur et al., 2019). Dengan memberikan masalah open-ended dan masalah kontekstual dapat memberikan tantangan bagi siswa untuk menyelesaikan masalah tersebut (Firdaus et al., 2015; NCTM, 2000). Masalah open-ended memberikan keleluasaan bagi siswa untuk menyelesaikan masalah serta berargumen tentang solusi yang diberikan. Siswa dapat melakukan aktivitas tersebut dalam tahapan Problem Based Learning bagian mengidentifikasi masalah atau bagian yang terdapat kegiatan memecahkan masalah. Namun, dalam menyelesaikan masalah siswa harus banyak berlatih agar kemampuan berpikir kritisnya dapat terus berkembang. Kemampuan siswa dalam bertahan menghadapi masalah disebut Adversity Quotient. Stoltz menyatakan bahwa AQ merupakan kecerdasan siswa dalam menghadapi masalah, merespon masalah tersebut dan memanfaatkan masalah menjadi sebuah peluang (Stoltz, 2005). Penelitian Nurlaeli menyatakan bahwa pembelajaran model Problem Based Learning untuk meningkatkan kemampuan berpikir kritis ditinjau dari Adversity Quotient mengalami peningkatan yang signifikan dan terdapat pengaruh antara yang memiliki AQ tinggi/rendah dengan penerapan model Problem Based Learning ataupun tanpa model tersebut. Nurlaeli memaparkan bahwa siswa yang memiliki AQ tinggi, Kemampuan Berpikir Kritisnya lebih tinggi menggunakan model Problem Based Learning daripada pembelajaran konvensional. Namun, Kemampuan Berpikir kritis siswa tidak memberikan pengaruh terhadap siswa yang memiliki AQ rendah, baik menggunakan model Problem Based Learning maupun konvensional (Nurlaeli et al., 2018).

\section{Kemampuan Berpikir Kreatif}

Salah satu tujuan pendidikan adalah mengembangkan potensi siswa diantaranya menjadi pribadi yang kreatif (UU RI No. 20 Tahun 2003, 2003). Menurut Purnomo, Kemampuan Berpikir Kreatif dapat berkembang jika siswa juga menggunakan Kemampuan Pemecahan Masalah terlebih dahulu dalam menyelesaikan masalah matematika (Kosiret et al., 2021; Purnomo et al., 2015). Hal ini dibuktikan juga dalam penelitian Wafik bahwa terdapat pengaruh positif hingga $37 \%$ antara kemampuan berpikir kritis dengan kemampuan pemecahan masalah, sisanya adalah faktor lain (Khoiri \& Cahyono, 2013). Dengan pemecahan masalah, siswa dapat mengurai masalah menjadi lebih sederhana dan berlanjut ke tahapan berikutnya yaitu menyelesaikan masalah dengan berpikir kreatif. Menurut siswono, terdapat lima tingkatan dalam berpikir kreatif yaitu :

1. Tingkat Berpikir Kreatif 4 (Sangat Kreatif) memiliki karakteristik siswa dapat menjawab lebih dari satu jawaban atau siswa memiliki penyelesaian dengan cara yang berbeda dengan lancar dan fleksibel.

2. Tingkat Berpikir Kreatif 3 (Kreatif) memiliki karakteristik siswa dapat menyelesaikan masalah dengan penjelasan yang berbeda yang artinya siswa fleksibel walaupun tidak terlalu fasih, ataupun sebaliknya. 
3. Tingkat Berpikir Kreatif 2 (Cukup Kreatif) memiliki karakteristik siswa dapat menjawab dengan satu jawaban yang berbeda dari kebiasaan walaupun tidak terlalu fasih atau fleksibel. Bisa juga siswa menjawab dengan jawaban berbeda walaupun sudah pernah terjawab sebelumnya dengan fasih dan fleksibel.

4. Tingkat Berpikir Kreatif 1 (Kurang Kreatif) memiliki karakteristik siswa tidak bisa menjawab dengan jawaban berbeda atau bisa menjawab satu jawaban tetapi sudah pernah terjawab sebelumnya. hal ini mengindikasikan siswa menjawab dengan jawaban fasih tapi tidak fleksibel atau fleksibel namun tidak fasih.

5. Tingkat Berpikir Kreatif 0 (Tidak Kreatif) memiliki karakteristik siswa benar-benar tidak mampu menjawab dengan cara yang lain. Dapat dikategorikan bahwa siswa ini tidak fasih maupun fleksibel.

Inti dari indikator penilaian TBK oleh Siswono adalah pada kefasihan dan fleksibilitas siswa dalam menjawab soal dengan cara yang berbeda, menjelaskan dengan penjelasan yang berbeda dan membuat soal dengan masalah yang berbeda (T. Y. E. Siswono, 2007). Adapun indikator berpikir kreatif lain yaitu menurut De Bono dalam Barak \& Doppelt (Barak \& Doppelt, 2000), berpikir kreatif memiliki empat tahapan yaitu kesadaran berpikir dimana siswa menggunakan kesadaran umum tentang berpikir sebagai suatu keterampilan, kesediaan untuk menyelidiki suatu subjek dan kesediaan mendengarkan orang lain. Berikutnya adalah tahap observasi berpikir terhadap tindakan dan pilihan, observasi dari sudut pandang siswa lain dan perbandingan relatif. Kemudian strategi berpikir menggunaan alat berpikir, mengorganisasikan pemikiran secara berurut dan memperkuat tujuan berpikir. Terakhir, refleksi berpikir yaitu menggunakan alat yang terstruktur, kesadaran penuh tentang pemikiran reflektif, evaluasi pemikiran dari diri sendiri dan merencanakan tugas berpikir serta metode untuk melaksanakannya.

Kemampuan berpikir kreatif siswa dapat berkembang pada tahapan awal yaitu kesadaran berpikir dan observasi dimana siswa harus sadar terlebih dahulu akan aktivitas yang sedang ia lakukan dan menggali potensi kreatifnya semaksimal mungkin. Menurut Moses, berpikir kreatif siswa bisa berkembang apabila guru memodifikasi masalah-masalah yang ada pada buku teks dan mengajukan masalah yang mempunyai jawaban lebih dari satu. Apabila masalah yang disajikan memiliki jawaban tunggal maka siswa hanya perlu mengikuti alur penyelesaian sesuai dengan yang sudah ada. Hal ini tidak mendorong siswa untuk berpikir lebih kreatif dengan caranya masing-masing dan membatasi kreativitas siswa (Cahyaningsih \& Ghufron, 2016; Tatag Yuli Eko Siswono, 2005). Problem Based Learning memfasilitasi siswa dalam membentuk kontruksi masalah dari pengetahuan yang telah siswa miliki. Tahapan kognitif siswa yang berbeda-beda menjadikan siswa memiliki jawaban yang berbedabeda pula. Hal ini memberikan dampak positif dalam pembelajaran karena siswa akan lebih aktif, semangat dan antusias dalam pembelajaran karena siswa bisa bebas berpendapat (Cahyaningsih \& Ghufron, 2016). Siswa dengan kreatifitasnya masing-masing dapat menjawab suatu masalah dengan penjelasan dan cara menjelaskan yang berbeda-beda. 
Dalam penelitian Purnomo, Kemampuan Berpikir Kreatif siswa dapat meningkat dengan penerapan model Problem Based Learning ditinjau dari Gaya Kognitif siswa pada mata pelajaran Geometri (Purnomo et al., 2015). Purnomo menggunakan indikator berpikir kreatif Siswono dengan 5 tingkatan berpikir kreatif. Gaya kognitif yang diteliti adalah kognitif impulsif dan kognitif reflektif. Kognitif Impulsif adalah gaya kognitif siswa yang kurang teliti dan cenderung menjawab salah namun cepat menjawab masalah yang diberikan, sedangkan kognitif reflektif adalah gaya kognitif siswa yang teliti dan cenderung menjawab benar namun lambat dalam menjawab. Dalam penelitian tersebut menghasilkan bahwa penerapan Problem Based Learning dalam meningkatkan kemampuan berpikir kreatif siswa dengan ciri kognitif reflektif cenderung memiliki tingkat berpikir kreatif yang tinggi seiring dengan tingginya rasa ingin tahu. Disisi lain siswa dengan kognitif impulsif bisa memiliki tingkat berpikir kreatif yang sangat rendah atau pun bahkan sangat tinggi melebihi kognitif reflektif.

Penemuan yang bervariasi ini juga terdapat dalam penelitian Adi Satrio. Perlu ditegaskan bahwa tidak semua siswa dengan perolehan nilai yang baik sudah pasti memiliki kemampuan berpikir kreatif yang baik pula. Adi Satrio dalam penelitiannya membuktikan bahwa dari enam siswa yang memiliki nilai UTS dalam interval rata-rata, memiliki tingkat kemampuan berpikir kreatif yang bervariatif mulai dari TKBK 1-4 (Ardiansyah et al., 2015). Hal ini mengindikasikan bahwa masih mungkin siswa dengan kemampuan intelektual yang lemah memiliki tingkat kemampuan berpikir kreatif yang tinggi.

Dalam penelitian Wafik menghasilkan bahwa dengan model Problem Based Learning berbantu multimedia, kemampuan berpikir kreatif siswa telah mencapai ketuntasan klasikal yang artinya lebih dari sama dengan 85\% siswa telah tuntas dalam belajarnya (Trianto Ibnu Badar Al-Tabany, 2014). Selain itu, kemampuan berpikir kreatif siswa meningkat dengan menggunakan model Problem Based Learning berbantu multimedia dan lebih baik dibandingkan dengan pembelajaran ekspositori (Khoiri \& Cahyono, 2013).

\section{Kemampuan Pemecahan Masalah}

NCTM menjelaskan bahwa dalam pembelajaran matematika dibutuhkan pengetahuan baru melalui proses pemecahan masalah, memecahkan masalah dengan ilmu matematika, menggunakan berbagai strategi untuk memecahkan masalah, dan mengamati serta mengembangkan proses pemecahan masalah (NCTM, 2000). Kemampuan Pemecahan Masalah menjadi kemampuan yang penting sebagai landasan berpikir kritis dan kreatif (Purnomo et al., 2015; Sri Elita et al., 2019). Keterkaitan kemampuan pemecahan masalah dengan model Problem Based Learning adalah siswa dapat berdiskusi secara kelompok dan menyampaikan pendapat dari pengetahuan yang telah didapat sebelumnya atau pada tahapan menyampaikan hasil dan evaluasi yang dilakukan oleh kelompok siswa yang lebih besar (kelas) dari sebelumnya (kelompok) (Sri Elita et al., 2019). Siswa akan lebih paham karena langsung terlibat dalam menggali ilmu pengetahuan, mulai dari memahami masalah yang diberikan hingga memaparkan hasilnya serta dievaluasi kembali (Yusri, 2018). Kemampuan Pemecahan Masalah memiliki beberapa langkah diantaranya, 
1. Memahami masalah: Pada tahapan awal, siswa mengetahui isi dari seluruh informasi yang ada pada soal. Mulai dari apa yang menjadi fakta, apa yang ditanyakan, tujuan solusi, dan kekurangan untuk mencapai solusi tersebut.

2. Membuat rencana pemecahan: Ketika membuat rencana pemecahan, siswa akan masuk pada proses mengkoneksikan pengetahuan dengan apa yang ditanyakan. Perjalanan siswa menuju kepada solusi permasalahan.

3. Menjalankan rencana pemecahan

4. Memeriksa hasil pemecahan masalah: Siswa perlu mengecek kembali apakah permasalahan sudah tuntas atau belum, serta apakah cara yang digunakan benar atau tidak.

Pada penelitian Nadhifah, model pembelajaran Problem Based Learning menghasilkan peningkatan pada pembelajaran, walaupun pada praktiknya masih ada anak yang memilih untuk pasif ketika bekerja secara berkelompok. Hal ini dikatakan peneliti karena siswa tidak memiliki pengetahuan yang cukup luas, sehingga ketika proses pembelajaran secara berkelompok, siswa tersebut tidak bisa aktif (Nadhifah \& Afriansyah, 2016). Menjadi catatan penting bahwa Problem Based Learning dapat di aplikasikan kepada siswa dengan pengetahuan yang cukup luas sehingga siswa juga dapat mengembangkan pengetahuan dari apa yang sudah ia ketahui. Selain itu, peneliti juga memakai model Inquiry dengan hasil tidak terdapat perbedaaan yang signifikan antara siswa yang menggunakan model Problem Based Learning dengan model Inquiry. Namun, didapat hasil kelas dengan model Problem Based Learning lebih aktif dibandingkan kelas Inquiry karena siswa dapat lebih aktif bertanya tentang hal-hal yang tidak mereka mengerti. Hal ini juga dilakukan dalam penelitian Sri Elita dengan membuat aturan khusus ketika berkegiatan kelompok yaitu siswa harus saling mendukung dan bekerja sama, serta setiap individu harus sadar akan tanggung jawabnya masing-masing. Diakhir pembelajaran, siswa akan mempresentasikan hasil pengerjaannya disertai dengan evaluasi (Hastuti et al., 2021; Sri Elita et al., 2019).

Proses Pemecahan Masalah dapat dikaitkan dengan karakteristik yang berbeda-beda dari tiap individu yaitu berdasarkan gaya kognitif (Arifin et al., 2019; Ikram et al., 2021; Vendiagrys \& Junaedi, 2015). Gaya kognitif dibedakan menjadi kognitif field Independent dan field dependent dimana field Independent memiliki karakteristik belajar secara individu, menanggapi masalah dengan baik, dan tidak bergantung pada orang lain, sedangkan field dependent memiliki karakteristik belajar secara berkelompok baik dengan sesama murid maupun guru dengan tujuan mendapatkan penguatan yang bersifat ekstrinsik sebanyak-banyaknya. Hasilnya adalah siswa dengan gaya kognitif field Independent memiliki kemampuan pemecahan lebih baik dibandingkan kognitif field dependent. Guru perlu memperhatikan siswa dengan gaya kognitif field dependent. Dalam penelitian ini, guru menginisiasi solusinya dengan model Remedial Teching dengan mengelompokkan siswa berdasarkan gaya kognitifnya. Selanjutnya pembahasan ini akan lebih lengkap didalam penelitian yang lebih fokus terhadap gaya kognitif siswa 
Pada tahapan Problem Based Learning, kedua jenis gaya kognitif memiliki karakteristik yang berbeda. Siswa dengan kemampuan field Independent dapat memahami masalah dengan baik, dapat mengubah masalah tersebut kedalam bentuk matematika, dapat memanfaatkan pengetahuan yang sudah ada beserta langkah-langkah untuk menemukan jawaban, dapat memecahkan masalah dengan konteks kehidupan nyata.

Dalam penelitian Sri Elita (Sri Elita et al., 2019), model Problem Based Learning dilakukan dengan pendekatan metakognisi. Metakognisi berperan penting dalam pemecahan masalah karena metakognisi adalah kemampuan seseorang melihat diri sendiri secara sadar sehingga apa yang dilakukan dapat dikontrol secara sadar. Dari sini siswa sadar akan proses berpikirnya dan bisa secara mandiri mengevaluasi hal-hal yang menjadi kesalahan siswa. Hal ini juga dapat membantu guru dalam menemukan kekurangan atau hal yang belum siswa mengerti.

\section{KESIMPULAN}

Tujuan pembuatan artikel ini adalah untuk mengetahui apa saja kemampuan matematis yang berkembang jika menerapkan model Problem Based Learning dalam pembelajaran. Pemilihan model pembelajaran penting untuk meningkatkan kompetensi siswa. Dalam model Problem Based Learning dapat meningkatkan beberapa kemampuan matematis diantaranya kemampuan berpikir kritis, kemampuan berpikir kreatif, dan kemampuan pemecahan masalah. tiga kemampuan ini memiliki keterkaitan satu sama lain dan beberapa penelitian telah membuktikan bahwa dengan menambahkan strategi khusus, seperti dipadukan dengan menambahkan model kooperatif, dapat meningkatkan kemampuan siswa lebih baik. Selain itu, beberapa kecerdasan siswa meningkat terbukti oleh penelitian yang sudah dibahas.

Saran untuk para pendidik, diharapkan mampu melihat urgensi dari pemberian pendidikan matematika untuk siswa. Bahwa banyak kemampuan matematis siswa yang akan berkembang apabila guru pandai memilih model pembelajaran dan menciptakan suasana belajar yang hidup agar nantinya dapat dimanfaatkan siswa dalam kehidupan nyata. Keterbatasan penulis dalam meniliti artikel ini, menyarankan peneliti yang membaca untuk meneliti lebih lanjut tentang pengaruh Problem Based Learning terhadap kemampuan matematis siswa yang lainnya.

\section{UCAPAN TERIMA KASIH}

Terima kasih kepada Allah subhanahu wa ta'ala, dosen pembimbing Bapak Makmuri dan Bapak Tian Abdul Aziz, dan teman-teman Universitas Negeri Jakarta.

\section{DAFTAR PUSTAKA}

Alawiyah, F. (2013). Peran Guru dalam Kurikulum 2013. Aspirasi, 4(1), 65-74.

Ardiansyah, A. S., Junaedi, I., \& Asikin, M. (2015). Eksplorasi Tingkat Kemampuan Berpikir Kreatif Siswa Kelas VIII pada Pembelajaran Matematika Setting Problem Based Learning. Prosiding Seminar Nasional Matematika IX, 336-345. 
Arifin, S., Kartono, K., \& Hidayah, I. (2019). Analisis Kemampuan Pemecahan Masalah Pada Model Problem Based Learning Disertai Remedial Teaching. Eduma : Mathematics Education Learning and Teaching, 8(1), 85-97. https://doi.org/10.24235/eduma.v8i1.3355

Barak, M., \& Doppelt, Y. (2000). Using Portfolios to Enhance Creative Thinking. The Journal of Technology Studies, 26(2), 16-25. https://doi.org/10.21061/jots.v26i2.a.3

Barrett, T. (2016). Understanding Problem-Based Learning. April.

Cahyaningsih, U., \& Ghufron, A. (2016). Pengaruh Penggunaan Model Problem-Based Learning Terhadap Karakter Kreatif Dan Berpikir Kritis Dalam Pembelajaran Matematika. Jurnal Pendidikan Karakter, 1, 104-115. https://doi.org/https://doi.org/10.21831/jpk.v0i1.10736

Facione, P. A. (2015). Critical Thinking: What It Is and Why It Counts. 5(1), 1-30.

Fathurrohman. (2001). Model-Model Pembelajaran. VDI Berichte, 1589, 105-112.

Firdaus, F., Kailani, I., Bakar, M. N. Bin, \& Bakry, B. (2015). Developing Critical Thinking Skills of Students in Mathematics Learning. Journal of Education and Learning (EduLearn), 9(3), 226. https://doi.org/10.11591/edulearn.v9i3.1830

Fisher, A. (2009). Berpikir Kritis. Erlangga.

Foundation for Young Australians. (2016). The New Basics: Big data reveals the skills young people need for the New Work Order FYA's New Work Order report series. 24.

Gunur, B., Ramda, A. H., \& Makur, A. P. (2019). Pengaruh Pendekatan Problem Based Learning Berbantuan Masalah Open-Ended Terhadap Kemampuan Berpikir Kritis Ditinjau Dari Sikap Matematis Siswa. JOHME: Journal of Holistic Mathematics Education, 3(1), 1.

Hastuti, E. S., Eclarin, L., \& Dalam, K. K. S. (2021). Kecemasan Siswa Sekolah Menengah Pertama Menyelesaikan Masalah SPLDV Pada Kelas Virtual Dalam. International Journal of Progressive Mathematics Education, 1(1), 64-84. https://doi.org/10.22236/ijopme.v1i1.6914

Ikram, M., Purwanto, \& Parta, I. N. (2021). Analysis of The Occurrence of Reversible Reasoning for Inverse Cases: A Case Study on The Subject Adjie. International Journal of Progressive Mathematics Education, 1(1), 1-15. https://doi.org/10.22236/ijopme.v1i1.6635

Joyce, B., Weil, M., \& Showers, B. (1992). Models of Teaching (4th ed.). Ally and Bacon.

Khoiri, W., \& Cahyono, A. N. (2013). Problem Based Learning Berbantuan Multimedia Dalam Pembelajaran Matematika Untuk Meningkatkan Kemampuan Berpikir Kreatif. Unnes Journal of Mathematics Education., 2(1). https://doi.org/10.15294/ujme.v2i1.3328

Kosiret, A., Indiyah, F. H., \& Wijayanti, D. A. (2021). The Use of Generative Learning Model in Improving Students' Understanding of Mathematical Concepts of Al-Azhar 19 Islamic High School. International Journal of Progressive Mathematics Education, 1(1), 1626. https://doi.org/10.22236/ijopme.v1i1.6593

Kusumaningtias, A., Zubaidah, S., \& Indriwati, S. E. (2013). Pengaruh Problem Based Learning dipadu Strategi Numbered Heads Together terhadap Kemampuan Metakognitif, Berpikir Kritis, dan Kognitif Biologi Siswa Kelas XI SMA Negeri 5 Malang.(TESIS). DISERTASI Dan TESIS Program Pascasarjana UM, 33-47.

Miao, Y., Holst, S. J., Haake, J. M., \& Steinmetz, R. (2020). PBL-protocols: Guiding and Controlling Problem Based Learning Processes in Virtual Learning Environments. International Conference of the Learning Sciences, 244-249. https://doi.org/10.4324/9780203763865-50

Nadhifah, G., \& Afriansyah, E. A. (2016). Peningkatan kemampuan pemecahan masalah matematis siswa dengan menerapkan model pembelajaran problem based learning dan inquiry. Mosharafa: Jurnal Pendidikan Matematika, 5(1), 33-44.

NCTM. (2000). Princples and Standards for School Mathematics. Journal of Equine Veterinary Science, 1-6. https://doi.org/10.1016/s0737-0806(98)80482-6 
Nurlaeli, N., Noornia, A., \& Wiraningsih, E. D. (2018). Pengaruh Model Pembelajaran Problem Based Learning Terhadap Kemampuan Berpikir Kritis Matematis Siswa Ditinjau Dari Adversity Quotient. FIBONACCI: Jurnal Pendidikan Matematika Dan Matematika, 4(2), 145. https://doi.org/10.24853/fbc.4.2.145-154

Partnership for 21st Century learning. (2009). 21st CENTURY STUDENT OUTCOMES. 1-9.

Pascarella, E., \& Terenzini, P. (2005). How college affects students: A third decade of research. 2.

Prasetya, S. P. (2013). MEMFASILTASI PEMBELAJARAN BERPUSAT PADA SISWA.

UU RI No. 20 Tahun 2003, Pub. L. No. 37 (2003).

Purnomo, D. J., Asikin, M., \& Junaedi, I. (2015). Tingkat Berpikir Kreatif Pada Geometri Siswa Kelas Vii Ditinjau Dari Gaya Kognitif Dalam Setting Problem Based Learning. Unnes Journal of Mathematics Education, 4(2). https://doi.org/10.15294/ujme.v4i2.7450

Schleicher, A. (2019). PISA 2018: insights and interpretations. OECD Publishing, 64.

Siswono, T. Y. E. (2007). Konstruksi Teoritik Tentang Tingkat Berpikir Kreatif Siswa Dalam Matematika. Jurnal Pendidikan, Forum Pendidikan Dan Ilmu Pengetahuan, 2(4), 1-10.

Siswono, Tatag Yuli Eko. (2005). Upaya Meningkatkan Kemampuan Berpikir Kreatif Siswa Melalui Pengajuan Masalah. Pendidikan Matematika, 1, 1-15.

Sri Elita, G., Habibi, M., Putra, A., \& Ulandari, N. (2019). Pengaruh Pembelajaran Problem Based Learning dengan Pendekatan Metakognisi terhadap Kemampuan Pemecahan Masalah Matematis. Mosharafa: Jurnal Pendidikan Matematika, 8(3), 447-458.

Stoltz, P. G. (2005). Adversity Quotient: Mengubah Hambatan Menjadi Peluang (6th ed.). Grasindo.

Sunardi. (2016). Strategi Penguatan Pengembangan 4c's Dalam Pembelajaran Matematika. Prosiding Seminar Nasional Pendidikan Matematika, 8-19.

Trianto Ibnu Badar Al-Tabany. (2014). Mendesain model pembelajaran inovatif, progresif, dan kontekstual. In T. T. T. Trianto (Ed.), Kencana Prenadamedia Group. Prenadamedia Group.

Vendiagrys, L., \& Junaedi, I. (2015). Analisis Kemampuan Pemecahan Masalah Matematika Soal Setipe Timss Berdasarkan Gaya Kognitif Siswa Pada Pembelajaran Model Problem Based Learning. Unnes Journal of Research Mathematics Education, 4(1), 34-41.

Wulandari, B., \& Surjono, H. D. (2013). Pengaruh problem-based learning terhadap hasil belajar ditinjau dari motivasi belajar PLC di SMK. Jurnal Pendidikan Vokasi, 3(2), 178191. https://doi.org/10.21831/jpv.v3i2.1600

Yulianti, E., \& Gunawan, I. (2019). Model Pembelajaran Problem Based Learning (Pbl): Efeknya Terhadap Pemahaman Konsep Dan Berpikir Kritis Problem Based Learning (Pbl) Learning Model: the Effect on Understanding of Concept and Critical Thinking. Indonesian Journal of Science and Mathematics Education, 02(November), 399-408.

Yusri, A. Y. (2018). Pengaruh Model Pembelajaran Problem Based Learning Terhadap Kemampuan Pemecahan Masalah Matematika Siswa Kelas Vii Di Smp Negeri Pangkajene. Mosharafa: Jurnal Pendidikan Matematika, 7(1), 51-62. https://doi.org/10.31980/mosharafa.v7i1.341

How to cite : Prayuti, A., Aziz, T. A., \& Makmuri., 2021. Studi Literatur: Pengaruh Problem Based Learning Terhadap Kemampuan Matematis Siswa. Jurnal Riset Pendidikan Matematika Jakarta. 3(2). 42-53. https://doi.org/10.21009/jrpmj.v3i2.22266

To link to this article: $\underline{\text { https://doi.org/10.21009/jrpmj.v3i2.22266 }}$ 